\title{
ANALISIS PENGARUH SEKTOR EKONOMI MEMILKI NILAI LQ LEBIH BESAR DARI SATU TERHADAP PENINGKATAN KESEJAHTERAAN MASYARAKAT KOTA DI SUMATERA UTARA
}

\author{
Dr. M. Nasir, MS \\ Dosen Universitas Negeri Medan (UNIMED) \\ email : nasir_muhammad11@yahoo.co.id
}

\begin{abstract}
ABSTRAK
Penelitian ini dilatarbelakangi oleh wilayah propinsi Sumatera Utara memiliki delapan Kotamadya, masing-masing Kotamadya memiliki sektor ekonomi yang berbeda dalam memberikan tingkat kesejahteraan masyarakat, permasalahannya adalah sektor ekonomi apa saja yang memberi kontribusi terhadap peningkatan kesejahteraan masyarakat dan berapa besar pengaruh dari sektor ekonomi tersebut. Tujuan penelitian untuk mengetahui sektor ekonomi yang memberi kontribusi terhadap peningkatan kesejahteraan masyarakat dan besaran pengaruh dari sektor ekonomi tersebut. Untuk mengetahui sektor ekonomi yang berpengaruh terhadap peningkatan kesejahteraan masyarakat digunakan model LQ. Sektor ekonomi yang memiliki nilai LQ lebih besar dari satu berarti sektor ekonomi tersebut berpengaruh terhadap peningkatan kesejahteraan masyarakat. Untuk mengetahui besarnya pengaruh dari sektor ekonomi tersebut digunakan model regresi liner berganda dengan model : $Y_{i}=\alpha_{0}+\alpha_{1} X_{1}+\alpha_{2} X_{2}+$ $\alpha_{3} X_{3}+\ldots \alpha_{n} X_{n}+\epsilon$, Penelitian ini menggunakan data time series tahun 1993 sampai dengan 2015 yang diambil dari BPS Sumatera utara.

Hasil penelitian menunjukkan bahwa sektor ekonomi yang memiliki nilai LQ lebih besar dari satu (berpengaruh terhadap tingkat kesejahteraan masyarakat ) adalah sektor ekonomi bangunan, sektor ekonomi perdagangan, sektor ekonomi transportasi dan sektor ekonomi jasa.

Untuk kota Sibolga sektor ekonomi transportasi berpengaruh positif dan signifikan terhadap tingkat kesejahteraan masyarakat. Kota Tanjung balai sektor ekonomi bangunan dan sektor ekonomi jasa berpengaruh positif dan signifikan terhadap tingkat kesejahteraan masyarakat. Kota pematang Siantar sektor ekonomi bangunan dan sektor ekonomi jasa berpengaruh positif dan signifikan terhadap tingkat kesejahteraan masyarakat. Kota Tebing tinggi sektor ekonomi bangunan dan sektor ekonomi perdagangan berpengaruh positif dan signifikan terhadap tingkat kesejahteraan masyarakat. Kota Medan sektor ekonomi jasa berpengaruh positif dan signifikan terhadap tingkat kesejahteraan masyarakat. Kota Binjai sektor ekonomi bangunan dan sektor ekonomi jasa berpengaruh positif dan signifikan terhadap tingkat kesejahteraan masyarakat. Kota Padang sidimpuan sektor ekonomi perdagangan berpengaruh posotif dan signifikan tingkat kesejahteraan masyarakat. Kota Gunung Sitoli sektor ekonomi bangunan dan sektor ekonomi perdagangan berpengaruh posotif dan signifikan terhadap tingkat kesejahteraan masyarakat.

Sektor ekonomi yang berpengaruh positif dan signifikan yang telah dinyatakan diatas dapat ditingkatkan efisiensi dan operasinya karena sektor ekonomi tersebut dapat meningkatkan tingkat kesejahteraan masyarakat.
\end{abstract}

Kata kunci : Sektor ekonomi memiliki nilai LQ lebih besar dari satu, tingkat kesejahteraan Masyarakat kota 


\section{PENDAHULUAN}

Peningkatan kesejateraan masyarakat pada suatu tempat terjadi karena adanya penambahan jumlah barang dan jasa (out put) yang dihasilkan masyarakat ditempat tersebut. Jumlah barang dan jasa yang dihasilkan berasal dari sumberdaya yang dimiliki, berupa sumberdaya alam dan sumberdaya manusia. Barang dan jasa yang dihasilkan terdiri dari beberapa sektor, masing-masing sektor tidak sama dalam memberikan pengaruh terhadap peningkatan kesejahteraan masyarakat. Ada sektor ekonomi memberikan pengaruh yang besar terhadap peningkatan kesejahteraan masyarakat. Pada sisi lain ada juga yang memberikan pengaruh yang rendah, bahkan ada yang tidak memberikan pengaruh sama sekali sehingga untuk memenuhi kebutuhan barang dan jasa harus didatangkan dari daerah lain. Berkaitan terhadap situasi ini perlu bagi suatu daerah untuk meneliti sektor ekonomi yang memberikan sumbangan yang besar terhadap peningkatan kesejahteraan masyarakat. Diketahuinya sektor ekonomi yang memberikan sumbangan yang besar terhadap peningkatan kesejahteraan masyarakat maka pemerintah dan pelaku ekonomi di wilayah tersebut perlu membuat strategi dan kebijakan tertentu berkaitan dalam usaha untuk meningkatkan jumlah produk yang dihasilkan dari sektor ekonomi yang memberikan kontribusi besar terhadap kesejahteraan masyarakat.

Untuk mengetahui jumlah barang dan jasa yang dihasilkan dari sektor ekonomi pada suatu wilayah dapat dilihat pada data dalam PDRB. PDRB suatu wilayah menggambarkan jumlah barang dan jasa yang dihasilkan bersumber dari sector-sektor ekonomi yang ada pada wilyah tersebut selama satu periode tertentu, biasanya selama satu tahun. Untuk melihat kelebihan maupun kekurangan dan keadaan sektor ekonomi yang ada di Sumatera Utara perlu kiranya membandingkan angka-angka PDRB Sumatera Utara dengan PDRB yang dimiliki wilayah tetangganya (Aceh) dan GNP Indonesia hal ini perlu dilakukan agar keberadaan sektor ekonomi yang ada di Sumatera Utara memliki nilai perbandingan, dari sini dapat diketahui keberhasilan ekonomi Sumatera Utara bila disetarakan dengan ekonomi wilayah Aceh dan Indonesia. PDRB selain menunjukan jumlah barang dan jasa yang dihasilkan pada suatu wilayah juga menggambarkan tingkat kesejahteraan masyarakat, tumbuh atau bertambahnya angkaangka PDRB berarti terjadi peningkatan tingkat kesejahteraan masyarakat. Berikut distribusi persentase tiga sektor ekonomi dominan dari PDRB/GNP menurut lapangan usaha ADH konstan 2010 Sumatra Utara, Aceh dan Indonesia tahun 2013-2015.

Tabel 1

Distribusi Persentase Tiga Sektor Ekonomi Dominan Dari PDRB/GNP Menurut Lapangan Usaha ADH Konstan 2010 Sumatera Utara Aceh dan Indonesia Tahun 2013-2015 (\%)

\begin{tabular}{|l|c|c|c|c|c|c|c|c|c|}
\hline SEK.EKO. & \multicolumn{3}{|c|}{ SUMATERA UTARA } & \multicolumn{3}{c|}{ ACEH } & \multicolumn{3}{|c|}{ INDONESIA } \\
\cline { 2 - 10 } DOMINAN & 2013 & 2014 & 2015 & 2013 & 2014 & 2015 & 2013 & 2014 & 2015 \\
\hline $\begin{array}{l}\text { Pertanian, kehutanan } \\
\text { dan perikanan }\end{array}$ & 25,05 & 24,85 & 24,97 & 25,93 & 26,16 & 27,63 & 13,28 & 13,18 & 13,04 \\
\hline Instri, pengolahan & 20,23 & 19,79 & 19,52 & 7,91 & 7,19 & 5,70 & 21,72 & 21,65 & 21,54 \\
\hline $\begin{array}{l}\text { Perdagangan besar, } \\
\text { eceran, reparasi } \\
\text { mobil dan sepeda } \\
\text { motor }\end{array}$ & 17,31 & 17,59 & 17,47 & 14,68 & 15,04 & 15,74 & 13,72 & 13,75 & 13,45 \\
\hline
\end{tabular}

Sumber : BPS Sumatera Utara. 
Provinsi Sumatera Utara pada tahun 2013 sektor pertanian berkontribusi kepada PDRB sebesar 25,05\%, pada tahun 2014 terjadi penurunan berubah menjadi 24,85\% dan pada tahun 2015 terjadi peningkatan berubah menjadi $24,97 \%$. Untuk sektor industri pengolahan pada tahun 2013 memberikan kontribusi sebesar 20,23\%, pada tahun 2014 terjadi penurunan berubah menjadi 19,79\%, pada tahun 2015 terjadi penurunan lagi berubah menjadi $19,51 \%$. Berikutnya sektor perdagangan besar, eceran, reparasi mobil dan sepeda motor pada tahun 2013 berkontribusi pada PDRB sebesar 17,31\%, pada tahun 2014 terjadi peningkatan berubah menjadi 17,59\% dan pada tahun 2015 terjadi penurunan berubah menjadi 17,47\%, perubahan kontribusi dari sektor ekonomi tersebut karena adanya fluktuasi ekonomi di Sumatera Utara.

Sebagai perbandingan pada provinsi tetangga yaitu Aceh Darusalam pada tahun 2013 sektor pertanian berkontribusi kepada PDRB Aceh sebesar 25,93\%, pada tahun 2014 terjadi peningkatan berubah menjadi 26,16\% dan pada tahun 2015 terjadi peningkatan lagi berubah menjadi 27,63\%, sektor ini selama 3 tahun bertutrut-turut terjadi peningkatan. Pada sektor industri pengolahan tahun 2013 berkontribusi pada PDRB Aceh sebesar 7,91\%, pada tahun 2014 terjadi penurunan berubah menjadi 7,19\%, pada tahun 2015 terjadi penurunan lagi berubah menjadi 5,70\%, sektor ini turun terus selama 3 tahun berturut. Berikut sektor perdagangan besar, eceran, reparasi mobil dan sepeda motor pada tahun 2013 memberi kontribusi pada PDRB Aceh sebesar 14,68\% dan pada tahun 2014 terjadi peningkatan berubah menjadi 15,04\% dan pada tahun 2015 terjadi peningkatan lagi berubah menjadi $15,74 \%$, sektor ini selama 3 tahun berturut terjadi peningkatan.

Selanjutnya bila dibandingkan pada wilayah Negara Indonesia yaitu pada tahun 2013 sektor pertanian memberi kontribusi pada GNP Indonesia sebesar 13,28\%, pada tahun 2014 terjadi penurunan berubah menjadi 13,18\% dan pada tahun 2015 terjadi penurunan lagi berubah menjadi 13,04\%, sektor pertanian selama 3 tahun berturut-turut mengalami penurunan menunjukkan adanya perubahan pola, sektor pertanian semakin kecil peranannya. Pada sektor industri pengolahan tahun 2013 memberi kontribusi pada GNP Indonesia sebesar 21,72\%, pada tahun 2014 terjadi penurunan berubah menjadi 21,65\%, pada tahun 2015 terjadi penurunan lagi berubah menjadi 21,54\% sektor ini terjadi penurunan terus selama 3 tahun berturut. Berikutnya sektor perdagangan besar, eceran, reparasi mobil dan sepeda motor pada tahun 2013 memberi kontribusi pada GNP Indonesia sebesar 13,72\% dan pada tahun 2014 terjadi peningkatan tipis berubah menjadi 13,75\% dan pada tahun 2015 terjadi penurunan berubah menjadi 13,45\%, sektor ini mengalami fluktuasi.

Untuk meningkatkan tingkat kesejahteraan masyarakat sektor industri harus diutamakan pertumbuhannya karena sektor industri dapat meningkatkan nilai tambah suatu produk.

Sektor ekonomi yang terdapat dalam PDRB memiliki LQ lebih besar dari satu merupakan hasil perbandingan dari data sector ekonomi yang ada dalam PDRB suatu wilayah dibandingkan dengan data sector ekonomi yang ada dalam PDRB wilayah yang lebih tinggi (lebih luas) Bila nilai LQ lebih besar dari satu menunjukkan bahwa produk (out put) yang memiliki LQ lebih besar dari satu tersebut jumlahnya cukup dan berlebih untuk memenuhi kebutuhan dari wilayah tersebut. Kelebihannya dijual (diekspor) kewilayah lain (wilayah tetangga) penerimaan dari hasil penjualan (ekspor) merupakan pendapatan yang dapat meningkatkan kesejahteraan masyarakat diwilayah tersebut. Nasir (2015) meningkatnya nilai LQ sektor pertanian meningkatkan tingkat pertumbuhan ekonomi di Kabupaten Sumatera Utara. Adanya pertumbuhan ekonomi 
suatu wilayah berarti jumlah barang dan jasa diwilayah tersebut jumlahnya meningkat, ini artinya adanya peningkatan kesejahteraan masyarakat diwilayah tersebut.

\section{Rumusan Masalah.}

Dari fenomena yang digambarkan diatas dapat ditemukan masalah penelitian ini yaitu apakah terdapat sector ekonomi yang memiliki nilai LQ lebih besar dari satu dan apakah berpengaruh signifikan terhadap peningkatan kesejahteraan masyarakat kota di Sumatera Utara.

\section{LANDASAN TEORITIS}

Peningkatan output merupakan indikator terjadinya pertumbuhan ekonomi, hal ini dapat merubah struktur perekonomian pada suatu wilayah. Masyarakat atau negara berusaha untuk memperbaiki struktur ekonominya dari perekonomian berbasis penghasil barang primer atau produk pertanian berusaha untuk merubah menjadi perekonomian dengan basis penghasil produk industri. Keinginan untuk merubah sektor industri lebih menjadi penting bila dibandingkan dengan sector pertanian dalam suatu perekonomian, dilatarbelakangi oleh keinginan untuk meningkatkan kesejahteraan masyarakat. Perekonomian didasarkan sektor industri memberikan nilai tambah yang lebih besar dalam menghasilkan barang/jasa sedangkan perekonomian yang didasarkan oleh sektor pertanian nilai tambah yang dihasilkan rendah bahkan dalam proses kegiatan produksi banyak ditentukan oleh faktor iklim, faktor ini sulit untuk direkayasa dalam usaha memberikan perlakuan agar dalam proses produksi memberikan hasil output yang optimal. Situasi ini dapat menimbulkan resiko dan bahkan membutuhkan waktu yang banyak dalam proses membuat produk. Samuelson (2004) menjelaskan terdapat empat unsur yang dapat meningkatkan ekonomi, yaitu : (a) sumberdaya manusia, Berupa penawaran tenaga kerja, tingkat pendidikan, disiplin, motivasi dan inovasi.; (b) sumberdaya alam, meliputi tanah, mineral, bahan bakar, kualitas lingkngan,(c) pembentukan modal, yaitu pendapatan , mesin, pabrik dan prasarana, sarana jalan.; (d) technology berupa sains, rekayasa, manajemen, kewirausahaan. Keempat unsur tersebut memiliki kontribusi yang besar kepada pertumbuhan ekonomi pada suatu wilayah.

Sumberdaya manusia merupakan unsur terpenting dalam usaha untuk meningkatkan output suatu wilayah, hal ini disebabkan karena manusia mempunyai kemampuan berfikir, berinovasi, berkreasi, menspesialisasikan diri dalam melakukan pekerjaan dalam upaya untuk meningkatkan efisiensi , disamping itu manusia dapat melakukan penyusunan organisasi dan pembentukan manajemen dalam penataan kegiatan produksi, mulai dari penyusunan rencana, pembentukan organisasi yang menjelaskan hubungan hak dan tanggung jawab antar bagian dalam kegiatan produksi, menggerakan dan mengarahkan seluruh pekerja untuk melakukan pekerjaan sesuai spesialisasi yang dimiliki, meningkatkan ilmu dan pengetahuan untuk meningkatkan produksi dan menemukan suatu inovasi yang kreatif, semua ini sangat berpengaruh signifikan terhadap pertumbuhan ekonomi suatu wilayah.

Unsur lain berpengaruh terhadap peningkatan output adalah sumberdaya alam, setiap wilayah mempunyai sumberdaya alam yang khas, pemilikan sumberdaya khas ini membuat suatu Negara mempunyai kemampuan berproduksi yang memiliki keunggulan komperatif. Baik keunggulan komperatif secara mutlak maupun keunggulan komperati secara relative. Produk seperti ini mempunyai nilai jual untuk diperdagangkan antar wilayah tetangga maupun antar negara (ekspor). Hasil dari 
penjualan produk akan memberikan masukan tambahan pendapatan bagi wilayah ini, berarti meningkatkan pertumbuhan ekonomi dan selanjutnya meningkatkan kesejahteraan bagi masyarakat dinegara bersangkutan.

Menurut teori ekonomi klasik modal berpengaruh positif terhadap pertumbuhan ekonomi suatu negara. Adanya peningkatan mesin pabrik, fasilitas peralatan, sarana akan menghasilkan terjadinya peningkatan jumlah barang dan jasa berarti terjadi pertambahan output yang dihasilkan kemudian dari sini akan meningkatan kesejahteraan diwilayah ini.

Kaum Neoklasik yang disampaikan oleh Solow berpendapat bahwa pertumbuhan pendapatan perkapita ekonomi Amerika Serikat disebabkan oleh kemajuan teknologi dan meningkatnya kemahiran serta keterampilan tenaga kerja. Perkembangan teknologi membuat kegiatan produksi semakin mudah, dari teknologi membantu tenaga kerja melakukan kerjanya menjadi sederhana dan mudah serta mampu menghasilkan barang dan jasa dengan berlipat ganda jumlahnya dan dengan pengeluaran biaya rata rata yang minimum, kemajuan teknologi berimpilkasi kepada efisiensi, penghematan waktu dan biaya dalam proses produksi. Ditinjau dari domain ekonomi regional pertumbuhan ekonomi pada suatu wilayah tidak sama dengan pertumbuhan ekonomi pada wilayah lain, hal ini terjadi karena dimasukkannya unsur ruang (space) dan lokasi. Meningkatnya perekonomian pada suatu wilayah ditentukan oleh sector ekonomi, yang terdapat dalam struktur PDRB, sector tersebut perlu diteliti untuk mencari sector ekonomi yang memiliki nilai LQ yang lebih besar dari satu. Sector ekonomi yang memiliki LQ lebih besar dari satu berindikasi bahwa sector ini merupakan penggerak pertumbuhan ekonomi disuatu wilayah.

\section{Teori Pertumbuhan NeoKalsik}

Teori pertumbuhan ekonomi Neoklasik didasarkan atas fungsi produksi Cobb-Douglas dapat ditunjukkan berikut ini

$Y_{t}=T_{t} K_{t}^{\alpha} L_{t}^{\beta}$

Keterangan:

$\mathrm{Y}_{\mathrm{t}}=$ Tingkat ekonomi tahun $\mathrm{t}$

$\mathrm{T}_{\mathrm{t}}=$ Tingkat teknologi tahun $\mathrm{t}$

$\mathrm{K}_{\mathrm{t}}=$ Tingkat modal tahun $\mathrm{t}$

$\mathrm{L}_{\mathrm{t}}=$ Tenaga Kerja tahun $\mathrm{t}$

$\alpha=$ Tambahan Produksi berasal dari pertambahan satu unit modal

$\beta=$ Tambahan produksi berasal dari pertambahan satu unit tenaga kerja

besaran $\mathrm{T}_{\mathrm{t}}, \alpha, \beta$ dapat diestimasi dari data empiris , diasumsikan $\alpha+\beta=1$, ini artinya $\alpha$ dan $\beta$ sama dengan produk marginal dari setiap faktor-faktor produksi.

Persamaan (1) dapat dibuat seperti berikut

$\log \mathrm{Y}_{\mathrm{t}}=\log \mathrm{T}_{\mathrm{t}}+\alpha \log \mathrm{K}_{\mathrm{t}}+\beta \log \mathrm{L}_{\mathrm{t}}$

Persamaan (2) diturunkan menjadi

$$
\begin{array}{rr}
\frac{\partial \log Y_{t}}{\partial t}=\frac{\partial \log T_{t}}{\partial t}+\propto \frac{\partial \log K_{t}}{\partial t}+\frac{\partial \log L_{t}}{\partial t} \\
\text { Bila } \quad \frac{\partial \log Y_{t}}{\partial t}=\gamma_{\mathrm{y}} & \frac{\partial \log K_{t}}{\partial t}=\gamma_{\mathrm{K}} \\
\frac{\partial \log T_{t}}{\partial t}=\gamma_{\mathrm{t}} & \frac{\partial \log L_{t}}{\partial t}=\gamma_{\mathrm{L}}
\end{array}
$$

Maka persamaan (3) dapat dituliskan sebagai berikut :

$\gamma_{\mathrm{Y}}=\gamma_{\mathrm{t}}+\alpha \gamma_{\mathrm{K}}+\beta \gamma_{\mathrm{L}}$ 


\section{Keterangan}

$\gamma_{\mathrm{Y}}=$ tingkat pertumbuhan ekonomi

$\gamma_{\mathrm{t}}=$ tingkat perkembangan teknologi

$\gamma_{\mathrm{k}}=$ tingkat peningkatan modal

$\gamma_{\mathrm{L}}=$ tingkat pertambahan tenaga kerja

Berikut jika dimasukkan unsur wilayah dalam analisis, model Neoklasik mengasumsikan perpindahan faktor produksi modal, tenaga kerja, teknologi pada awal proses pertumbuhan tidak lancar, hal ini disebabkan, faktor produksi tersebut biasanya terpusat pada wilayah yang lebih maju karena wilayah ini memiliki fasilitas ,kemudahan dalam kegiatan usaha. sehingga kesenjangan pertumbuhan ekonomi cenderung melebar. Bila mana proses pertumbuhan terus berlaku dimana fasilitas , kemudahan dalam usaha, sistem informasi sudah tertata baik maka perpindahan actor produksi modal, tenaga kerja, dan teknologi berjalan lancar, hal ini berimplikasi terhadap pertumbuhan ekonomi yang merata sehingga mengurangi tingkat kesenjangan.

\section{Model Pertumbuhan Interegional}

Model ini merupakan pengembangan dari teori basis ekspor yaitu dengan memperhitungkan pengaruh ekonomi dari antar wilayah melalui kegiatan perdagangan antar wilayah. Model pertumbuhan ekonomi interregional didasari oleh model pendapatan yang dikemukakan oleh Keynes, persamaannya sebagai berikut

$\mathrm{Y}_{\mathrm{i}}=\mathrm{C}_{\mathrm{i}}+\mathrm{I}_{\mathrm{i}}+\mathrm{G}_{\mathrm{i}}+\left(\mathrm{X}_{\mathrm{i}}-\mathrm{M}_{\mathrm{i}}\right)$

Persamaan (5) dapat diurai menjadi

$\mathrm{C}_{\mathrm{i}}=\mathrm{a}+\mathrm{b} \mathrm{Y}_{\mathrm{i}}$

Dimana

$\mathrm{C}_{\mathrm{i}}=$ Konsumsi

$\mathrm{a}=$ Tingkat konsumsi minimum

$\mathrm{b}=$ MPC

$\mathrm{Y}=$ Pendapatan

Persamaan ekspor dan impor untuk masing masing wilayah adalah

$\mathrm{X}_{\mathrm{i}}=\sum_{j=1}^{n} m_{i j} y_{j}$

$\mathrm{M}_{\mathrm{i}}=\sum_{j=1}^{n} m_{j i} y_{i}$

$\mathrm{m}=$ marginal prospensity to impor

persamaan penerimaan wilayah (pajak) adalah sebagai berikut

$\mathrm{Y}_{\mathrm{i}}=\mathrm{Y}_{\mathrm{i}}\left(1-\mathrm{t}_{\mathrm{i}}\right)$

$t_{i}$ persentase pemungutan pajak daerah $i$

Pengeluaran investasi dan pengeluaran pemerintah diasumsikan sebagai variabel autonomous yang ditetapkan diluar dari model ini dapat ditulis sebagai berikut

$\mathrm{I}_{\mathrm{i}}=\bar{I}_{\mathrm{i}}$

$\mathrm{G}_{\mathrm{i}}=\bar{G}_{\mathrm{i}}$

Dari sini dapat dituliskan pengeluaran total autonomous untuk wilayah $\mathrm{A}_{\mathrm{i}}$ dapat dituliskan sebagai berikut

$\mathrm{A}_{\mathrm{i}}=\mathrm{a}_{\mathrm{i}}+\bar{I}_{\mathrm{I}}+\bar{G}_{\mathrm{i}}$

Dari persamaan yang dikemukakan diatas diperoleh persamaan pendapatan regional sebagai berikut

$\mathrm{Y}_{\mathrm{i}}=\frac{\left|A_{i}+\sum_{j=1}^{n} m_{i j} y_{j}\left(1-t_{j}\right)\right|}{\left|1-\left(C_{i} \sum_{j=1}^{n} m_{j i}\right)(1-t)\right|}$

(Syafrizal, 2012). 
Persamaan tersebut menunjukkan bahwa pendapatan suatu wilayah terdiri dari penjumlahan pengeluaran autonomous ditambah dengan jumlah ekspor wilayah dan dikalikan dengan angka multiplier regional hal ini berdampak langsung terhadap pertumbuhan ekonomi suatu wilayah.

\section{Penentuan Nilai LQ}

Masing-masing daerah kota membuat rekaman berupa pengadministrasian terhadap jumlah barang dan jasa yang diproduksi paling tidak satu waktu tertentu biasanya satu tahun, dari rekaman administrasi tergambar struktur ekonomi daerah kota tersebut. Struktur ekonomi dapat menjelaskan sector-sektor ekonomi yang berpereran tinggi bagi peningkatan kesejahteraan masyarakat.

Perekaman administrasi jumlah barang dan jasa yang dihasilkan oleh suatu wilayah biasanya dilakukan dengan membuat PDRB (Produk Domestik Regional Bruto) untuk tingkat wilayah dan GNP ( Gross National Product) untuk tingkat Negara. Susunan PDRB dan GNP terdiri atas Sembilan sector ekonomi yaitu (a) sector prrtanian; (b) sector pertambangan / penggalian ; (c) sector industri ; (d) sector listrik, gas, dan air minum; (e) bangunan; (f) perdagangan, hotel, restoran; (g) pengangkutan ; (h) keuangan, asuransi ; (i) jasa-jasa. Rasio dari sector-sektor yang telah diutarakan tadi yaitu antara tingkat wilayah kota dengan tingkat propinsi hasilnya merupakan Location Quatient (LQ), rumusnya dapat ditunjukkan sebagai berikut

$$
L Q=\frac{\frac{s_{i}}{S}}{\frac{n_{i}}{N_{i}}}
$$

Perhitungan tersebut memberikan arti sebagai berikut :

LQ > 1, menunjukkan bahwa sector i didaerah yang dihitung ini mempunyai nilai lebih dibandingkan dengan wilayah tingkat provinsi atau dengan kota lain daerah ini menunjukkan sector i surplus, sehingga dapat diekspor kewilayah lain hal ini berarti dapat meningkatkan ekonomi wilayah ini.

LQ $<1$, menunjukkan bahwa sector i didaerah yang dihitung ini mempunyai nilai yang kecil dibandingkan dengan wilayah tingkat provinsi atau dengan kata lain daerah ini menunjukkan sector i tidak dapat memenuhi kebutuhan wilayah ini sendiri, untuk menutupinya harus diimpor dari wilayah lain, hal ini berarti terjadi kebocoran.

Analisis LQ dapat dihitung secara time series hasilnya dapat diregres dengan data pertumbuhan ekonomi kota-kota Sumatera Utara, hasilnya dapat mendeskripsikan dan estimasi pengaruh sector i terhadap pertumbuhan kesejahteraan ekonomi kota-kota di Sumatera Utara.

\section{Penelitian Sebelumnya.}

Pembahasan yang telah dilakukan sebelum ini bersifat teoritis belum lengkap bila tidak didampingi dengan pembahasan temuan temuan empiris yaitu hasil penelitian yang telah dilakukan oleh peneliti peneliti sebelum ini. Hasil dari peneliti sebelum ini dapat ditunjukkan diantaranya adalah

Nasir (2015), meningkatnya nilai LQ pada sektor pertanian dapat meningkatkan tingkat pertumbuhan ekonomi di Kabupaten Sumatera Utara.

I Dewa Made Darma Setiawan (2007), diprovinsi Jawa Timur bila dibandingkan dampak interregional kedua sektor unggulan maka sektor perdagangan memiliki dampak yang lebih besar dan kuat baik itu pada pertumbuhan output, pertumbuhan nilai tambah Bruto dan penciptaan lapangan kerja. Diprovinsi Bali kalau dibandingkan 
dampak interregional kedua sketor unggulan maka sektor hotel dan restoran memiliki dampak yang lebih besar dan kuat pada pertumbuhan output dan pertumbuhan nilai tambah bruto. Sedangkan sector pertenakan dan hasilnya memberikan dampak yang lebih besar pada penciptaan lapangan kerja.

Fatmasari Sukesti, Setia Irianto (2011), menemukan bahwa pengembangan komoditas unggulan merupakan strategi yang efektif dalam pengembangan ekonomi wilayah.

Dyla Novrilasari (2008), terdapat dua sektor yang menjadi basis perekonomian kabupaten Kuantan Singingi yang menjadi sektor unggulan pada tahun 2002 - 2006 yaitu sektor pertanian dan sektor pertambangan penggalian, hal ini menunjukkan bahwa sektor tersebut memiliki kontribusi yang besar dalam perekonomian dan pembangunan wilayah dikabupaten Kuantan Singingi.

Awaludin (2012), bahwa terdapat spesialisasi berpengaruh signifikan terhadap pertumbuhan ekonomi baik pada sektor unggulan maupun non unggulan.

Yunie Puspitasari M (2004) bahwa perlu adanya perhatian lebih pemerintah terhadap sektor unggulan guna mempercepat pertumbuhan ekonomi sekaligus dapat dipergunakan sebagai alat penggerak sektor lainnya sehingga dapat mencapai pertumbuhan optimal.

\section{METODOLOGI PENELITIAN}

\section{Ruang Lingkup Penelitian.}

Penelitian ini melihat seKtor ekonomi yang memiliki nilai LQ lebih besar dari satu dan pengaruhnya terhadap tingkat kesejahteraan masyarakat kota di Sumatra Utara. variabel yang diteliti meliputi nilai LQ dari seKtor ekonomi dan tingkat kesejahteraan (diproksi dengan tingkat pertumbuhan ekonomi) masyarakat di kota SumatEra Utara. Data yang digunakan bersifat Expost Facto bertujuan untuk mengetahui seKtor ekonomi yang memiliki nilai LQ lebih besar dari satu di wilayah perkotaan Sumatera Utara, selanjutnya melihat pengaruhnya terhadap peningkatan kesejahteraan masyarakat perkotaan di Sumatera Utara.

\section{Sumber Data.}

Data yang digunakan pada penelitian ini adalah data sector ekonomi yang terdapat pada PDRB Sumatra Utara dan PDRB kota-kota yang ada di Sumatra Utara priode tahun 1993 dan tahun 2015

\section{Metode Analisis}

Statistic Deskriptif

Alat ini digunakan untuk menggambarkan fenomena perekonomian wilayah perkotaan Sumatera Utara dan tingkat kesejahteraan (pertumbuhan) ekonomi Sumatera Utara.

Ordinary Least Squares (OLS).

Alat analisis ini digunakan untuk mengetahui besar pengaruh sector ekonomi yang memiliki nilai LQ lebih besar dari satu terhadap tingkat kesejahteraan masyarakat kota di Sumatra Utara, model yang digunakan sbb: $Y i=\alpha_{0}+\alpha_{1} X_{1}+\alpha_{2} X_{2}+\alpha_{3} X_{3}+$ $\ldots \alpha_{n} X_{n}+\epsilon$,

Dimana :

$\mathrm{Y}_{\mathrm{i}} \quad$ : Tingkat kesejahteraanmasyarakat kota i di Sumatra Utara. 


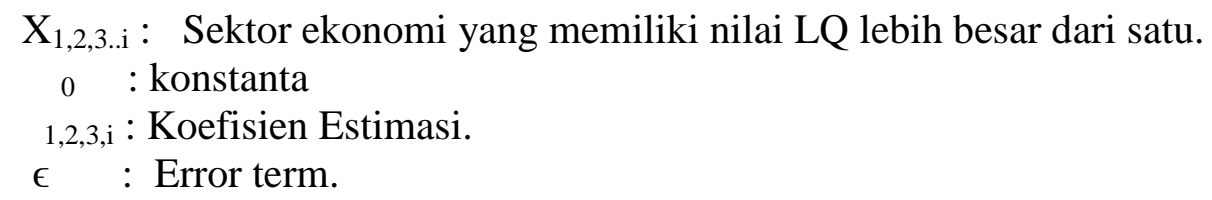

\section{HASIL DAN PEMBAHASAN \\ Perekonomian Sumatera Utara}

Perekonomian Sumatera Utara seKtor pertanian memberikan kontribusi cukup besar yaitu lebih kurang 23,83\% terutama pada seKtor perkebunan. Sumatera utara terkenal sebagai wilayah perkebunan, produk perkebunan yang dihasilkan diantaranya adalah kelapa sawit, karet, coklat, teh, kopi, kayu manis, tembakau, dan sebagainya. Berikutnya seKtor ekonomi yang berperan penting adalah seKtor industri pengolahan, seKtor ini menyumbang sebesar $22,89 \%$ hasil dari industri olahan diantaranya industri makanan, minuman, tekstil, kayu dan barang dari kayu, kertas, barang cetakan, dan barang lainnya. Selain yang telah diutarakan tadi seKtor perdagangan, hotel dan restoran juga turut mewarnai perekonomian Sumatera Utara, subseKtor perdagangan meliputi membeli dan menjual barang dengan tujuan untuk mendistribusikan tanpa merubah sifat barang yang diperdagangkan. SubseKtor hotel meliputi penyediaan jasa akomodasi menggunakan bangunan sebagai tempat tinggal. SubseKtor restoran meliputi usaha penyediaan makanan dan minuman seperti rumah makan, warung nasi, usaha catering, kantin dan sebagainya.

Secara rata-rata tingkat pertumbuhan ekonomi Sumatera Utara sebesar 5,2\% , angka tertinggi penah dicapai sebesar 9,47\% sebaliknya angka terendah penah diperoleh terpuruk sebesar $-10,9 \%$, anjloknya angka ini disebabkan terjadinya krisis ekonomi yang melanda Sumatera Utara yaitu pada tahun 1998, tahun-tahun berikutnya merangkak naik hingga sekarang tahun 2016 pertumbuhan ekonomi Sumatera Utara sebesar $5,7 \%$.

\section{Penetapan Sektor Eekonomi yang Memiliki Nilai LQ Lebih Besar Dari Satu}

Peningkatan ekonomi daerah yang disebabkan oleh sector ekonomi yang memiliki nilai LQ lebih besar dari 1 dapat menggerakan peningkatan kesejahteraan masyarakat, hal tersebut terjadi karena sector ekonomi ini diproduksi secara efisien dan hasilnya berlebih mampu memenuhi kebutuhan masyarakat di daerah itu sendiri serta kelebihannya di ekspor ke wilayah lain. Hasil ekspor tersebut merupakan peningkatan pendapatan bagi masyarakat, hal ini berarti terjadi dorongan untuk melakukan investasi. Dari investasi yang dilakukan akan meningkatkan permintaan atas barang modal dan tenaga kerja dengan adanya efek multiplier sangat berpengaruh kepada peningkatan kesejahteraan masyarakat.

Penetapan sector ekonomi yang memiliki nilai LQ lebih besar dari 1 dapat ditentukan dengan menggunakan rumus Locatioan Quation (LQ). PDRB ( Produk Domestik Regional Bruto) berisikan data sector-sektor ekonomi pada suatu daerah, data ekonomi sektor i daerah yang lebih rendah dibandingkan dengan data ekonomi sektor i pada daerah yang lebih luas (lebih tinggi) diperoleh nilai sektor ekonomi yang mempunyai nilai LQ. Bila nilai yang diperoleh lebih besar dari satu ini merupakan indikasi bahwa sektor ekonomi i yang berada di daerah ini mempunyai nilai lebih, artinya barang/jasa ini mampu memenuhi kebutuhan daerah ini dan berlebih, kelebihannya diekspor ke daerah lain sehingga meningkatkan pendapatan dan kesejahteraan daerah ini sendiri. Hasil perhitungan yang sudah dilakukan di kota-kota 
Sumatera Utara ditemukan sejumlah kota yang mempunyai sektor bangunan, sektor perdagangan, sektor transportasi dan sektor jasa mempunyai LQ lebih besar dari satu. Berikut Tabel 2 menunjukkan sektor ekonomi yang mempunyai nilai LQ lebih besar dari satu secara rata-rata dari tahun 1993-2014 di kota-kota Sumatera Utara.

Tabel 2

Nilai rata rata LQ lebih besar dari 1 dari Sektor ekonomi di kota Sumatra Utara

\begin{tabular}{|c|l|c|c|c|c|}
\hline No & \multicolumn{1}{|c|}{ Kota } & $\begin{array}{c}\text { LQ sektor } \\
\text { bagunan }\end{array}$ & $\begin{array}{c}\text { LQ sektor } \\
\text { perdagangan }\end{array}$ & $\begin{array}{c}\text { LQ sektor } \\
\text { transport }\end{array}$ & $\begin{array}{c}\text { LQ sektor } \\
\text { jasa }\end{array}$ \\
\hline 1 & Sibolga & - & 1,08 & 1,35 & 1,73 \\
\hline 2 & Tanjung Balai & 1,25 & 1,09 & - & 1,8 \\
\hline 3 & Pemantang Siantar & 1,24 & 1,38 & 1,58 & 1,26 \\
\hline 4 & Tebing Tinggi & 1,51 & 1,25 & 1,81 & 2,29 \\
\hline 5 & Medan & 1,49 & 1,29 & 1,80 & 1,09 \\
\hline 6 & Binjai & 1,50 & - & - & 1,63 \\
\hline 7 & Padang Sidimpuan & - & 1,34 & - & 2,06 \\
\hline 8 & Gunung Sitoli & 1,93 & 2,58 & - & - \\
\hline \multicolumn{5}{|l}{ Sumber: Hasil olahan }
\end{tabular}

Tabel di atas menunjukkan bahwa kota Sibolga memiliki sektor ekonomi yang mempunyai nilai LQ > 1 ada tiga sektor yaitu (a) sektor perdagangan dengan nilai LQ:1,08 (b) sektor transportasi nilai LQ: 1,35 (c) sektor jasa nilai LQ 1,73. Ketiga sektor ekonomi tersebut diperkirakan produksinya melebihi dari kebutuhan masyarakat di kota Sibolga. Kelebihan ini dipergunakan untuk perdagangan, bilamana perdagangan produk ini berjalan dengan efisien diperkirakan dapat meningkatkan pendapatan wilayah ini selanjutnya meningkatkan kesejahteraan masyarakat.

Demikian pula kota Tanjung Balai sector ekonomi yang memiliki nilai LQ > 1 ada tiga sektor yaitu (a) sektor bagunan Nilai LQ 1,25 (b) sektor perdagangan nilai LQ 1,09 dan (c) sektor jasa dengan nilai LQ 1,38. Jumlah produk dari ketiga sektor ekonomi tersebut melebihi dari yang diperlukan masyarakat kota Tanjungbalai, kelebihan ini dapat dijual ke wilayah lain, dari hasil penjualan ini memberikan masukan pendapatan bagi kota Tanjung Balai dan meningkatkan kesejahteraan masyarakat.

Untuk kota Pemantang Siantar produk dari sektor ekonomi yang memiliki nilai LQ lebih >1 terdapat empat sektor yaitu (a) sektor bagunan nilai LQ 1,24 (b) sektor perdagangan nilai LQ 1,38 (c) sektor transportasi nilai LQ 1,58, dan (d) Sektor Jasa niali LQ 1,26. Ke empat sektor ini mempunyai nilai lebih, oleh sebab itu nilai lebih tersebut dapat diekspor ke wilayah lain, hasil ekspor tersebut akan memberikan tambahan pendapatan, selanjutnya dapat meningkatkan kesejahteraan masyarakat Pematang Siantar.

Demikian juga terhadap Kota Tebing Tinggi, sektor ekonomi yang memiliki nilai LQ > 1 ada empat sektor yaitu ; (a) Sektor Bangunan nilai LQ 1,51 (b) Sektor Perdagangan nilai LQ 1,25 (c) Sektor transportasi nilai LQ 1,81, dan (d) Sektor Jasa nilai LQ 2,29. Ke empat sektor ekonomi ini dapat memberikan peningkatan pendapatan pada kota Tebing Tinggi kemudian meningkatkan tingkat kesejahteraan masyarakat.

Selanjutnya kota Medan sektor ekonomi yang memiliki nilai LQ > 1 ada empat sektor, yaitu: (a) Sektor Bangunan nilai LQ 1,49 (b) Sektor Perdagangan nilai LQ 1,29 (c) Sektor Tranportasi nilai LQ 1,86 dan (d) Sektor Jasa nilai LQ 2,09. Ke empat sektor 
ekonomi ini dapat memberikan peningkatan pendapatan pada Kota Medan dan selanjutnya akan meningkatkan tingkat kesejahteraan masyarakat.

Bagi kota Binjai sektor ekonomi yang mepunyai nilai LQ > 1 ada dua sektor, yaitu (a) Sektor bagunan nilai LQ 1,50 dan (b) Sektor jasa nilai LQ 1,63. Kedua sektor ekonomi ini dapat meningkatkan pendapatan bagi kota Binjai kemudian akan meningkatkan tingkat kesejahteraan masyarakat.

Selanjutnya untuk kota Padang Sidempuan sektor ekonomi yang mempunyai nilai LQ > 1 ada 2, yaitu (a) Sektor perdagangan nilai LQ 1,34 dan (b) Sektor Jasa nilai LQ 2,06, dari kedua sektor ekonomi ini kota Padang Sidempuan dapat menigkatkan pendapatan bagi daerahnya dan kemudian meningkatkan kesejahteraan masyarakat.

Terakhir kota Gunung Sitoli secara ekonomi yang mempunyai nilai IQ > 1 ada dua yaitu (a) Sektor Bangunan nilai LQ 1,93 (b) Sektor Perdagangan nilai LQ 2,85. Kedua sektro ekonomi ini dapat meningkatkan pendapatan bagi wilayah Gunung Sitoli kemudian meningkatkan kesejahteraan masyarakat.

\section{Hasil Estimasi Model Tingkat Kesejahteraan Masyarakat Kota di Sumatera Utara}

Berdasarkan uraian yang telah dilakukan pada kerangka teori dan kajian hasil penelitian empiris, dapatlah dibentuk fungsi tingkat kesejahtraan masyarakat kota di Sumatera Utara. Berkaitan dengan penelitian ini tingkat kesejahteraan (diproksi dengan tingkat pertumbuhan ekonomi ) merupakan fungsi dari sektor ekonomi yang memiliki nilai LQ $>1$. Berdasarkan olahan data yang telah dilakukan diperoleh hasil sebagai berikut :

Tabel 3

Hasil Estimasi Dari Model Tingkat Kesejahteraan Masyarakat Kota Sumatera Utara

\begin{tabular}{|c|c|c|c|c|c|c|c|}
\hline No & Wilayah kota & $\begin{array}{l}\text { Variabe } \\
\text { Bebas }\end{array}$ & Koef & $\begin{array}{l}\text { Sdtr } \\
\text { Eror }\end{array}$ & $\begin{array}{c}\mathrm{t} \\
\text { Statistik }\end{array}$ & $\begin{array}{l}\text { Probabilit } \\
\text { y }\end{array}$ & Ket \\
\hline \multirow[t]{2}{*}{1} & \multirow[t]{2}{*}{ Sibolga } & \begin{tabular}{l}
\multicolumn{1}{c}{$c$} \\
Sibolga \\
Trans
\end{tabular} & $\begin{array}{l}-0,502 \\
9,190\end{array}$ & $\begin{array}{l}1,013 \\
2,813\end{array}$ & $\begin{array}{l}-0,495 \\
3,267\end{array}$ & $\begin{array}{l}0,626 \\
0,0045\end{array}$ & $\begin{array}{l}\text { Tdk. Sig } \\
\text { Signifikan }\end{array}$ \\
\hline & & \multicolumn{6}{|c|}{$\begin{array}{l}\mathrm{R}^{2} \quad: 0,414 \\
\text { Prob F tes: } 0,024\end{array}$} \\
\hline \multirow[t]{3}{*}{2} & \multirow[t]{3}{*}{ Tanjung Balai } & $\begin{array}{c}\mathrm{C} \\
\text { T. Balai } \\
\text { bangunan }\end{array}$ & $\begin{array}{l}-8,64 \\
3,043\end{array}$ & $\begin{array}{l}2,862 \\
1,701\end{array}$ & $\begin{array}{l}-3,020 \\
1,788\end{array}$ & $\begin{array}{l}0,007 \\
0,089\end{array}$ & $\begin{array}{l}\text { Signifikan } \\
\text { Signifikan }\end{array}$ \\
\hline & & $\begin{array}{l}\text { T. Balai } \\
\text { Jasa }\end{array}$ & 7,464 & 1,821 & 4,098 & 0,0006 & Signfiikan \\
\hline & & \multicolumn{6}{|c|}{$\begin{array}{l}\mathrm{R}^{2} \quad: 0,573 \\
\text { Prob F tes }: 0,0003\end{array}$} \\
\hline \multirow[t]{3}{*}{3.} & \multirow[t]{3}{*}{ P. Siantar } & $\begin{array}{l}\mathrm{C} \\
\text { Siantar } \\
\text { bangunan }\end{array}$ & \begin{tabular}{l|l}
5,735 \\
1,946
\end{tabular} & $\begin{array}{l}2,885 \\
1,076\end{array}$ & $\begin{array}{l}1,987 \\
1,807\end{array}$ & $\begin{array}{l}0,061 \\
0,086\end{array}$ & $\begin{array}{l}\text { Signifikan } \\
\text { Signifikan }\end{array}$ \\
\hline & & Siantar Jasa & $-2,194$ & 1,837 & $-1,194$ & 0,29 & Tdk. Sig \\
\hline & & \multicolumn{6}{|c|}{$\begin{array}{l}\mathrm{R}^{2}: 0,226 \\
\text { Prob F tes } 0,087\end{array}$} \\
\hline 4 & T.Tinggi & $\mathrm{C}$ & $-37,04$ & 14,259 & 2,597 & 0,018 & Sig. \\
\hline
\end{tabular}




\begin{tabular}{|c|c|c|c|c|c|c|c|}
\hline & & $\begin{array}{l}\text { T. Tinggi } \\
\text { bangun }\end{array}$ & 7,548 & 3,397 & 2,221 & 0,039 & Sig \\
\hline & & $\begin{array}{l}\text { T. tinggi } \\
\text { dagang }\end{array}$ & $\begin{array}{l}20,22 \\
6\end{array}$ & 7,392 & 2,736 & 0,013 & Sig \\
\hline & & $\begin{array}{l}\mathrm{R}^{2}: 0, \\
\text { Prob F tes: } 0,\end{array}$ & & & & & \\
\hline 5 & \multirow[t]{2}{*}{ Medan } & $\begin{array}{l}\mathrm{C} \\
\text { Medan jasa }\end{array}$ & $\begin{array}{l}-9,77 \\
8,93\end{array}$ & $\begin{array}{l}5,626 \\
5,143\end{array}$ & $\begin{array}{l}-1,376 \\
1,737\end{array}$ & $\begin{array}{l}0,098 \\
0,098\end{array}$ & $\begin{array}{l}\text { Sig } \\
\text { Sig }\end{array}$ \\
\hline & & \multicolumn{6}{|c|}{$\begin{array}{l}\mathrm{R}^{2} \\
\text { Prob F tes }: 0,137 \\
0,098\end{array}$} \\
\hline \multirow[t]{3}{*}{6} & \multirow[t]{3}{*}{ Binjai } & $\begin{array}{l}\mathrm{C} \\
\text { Binjai jasa }\end{array}$ & $\begin{array}{l}-26,58 \\
14,19 \\
8\end{array}$ & $\begin{array}{l}12,610 \\
6,273\end{array}$ & $\begin{array}{l}-2,108 \\
2,263\end{array}$ & $\begin{array}{l}0,048 \\
0,035\end{array}$ & $\begin{array}{l}\text { Sig } \\
\text { Sig }\end{array}$ \\
\hline & & $\begin{array}{l}\text { Binjai } \\
\text { bangun }\end{array}$ & 6,250 & 2,559 & 2,441 & 0,024 & Sig \\
\hline & & \multicolumn{6}{|c|}{$\begin{array}{l}\mathrm{R}^{2}: 0,281 \\
\text { Prob F tes: } 0,043\end{array}$} \\
\hline \multirow[t]{2}{*}{7} & \multirow[t]{2}{*}{ P. Sidempuan } & $\begin{array}{l}\mathrm{C} \\
\text { P.sidempuan } \\
\text { dagang }\end{array}$ & $\begin{array}{l}-5,751 \\
4,398\end{array}$ & $\begin{array}{l}2,646 \\
1,962\end{array}$ & $\begin{array}{l}2,173 \\
2,240\end{array}$ & $\begin{array}{l}0,050 \\
0,044\end{array}$ & $\begin{array}{l}\text { Sig } \\
\text { sig }\end{array}$ \\
\hline & & \multicolumn{6}{|c|}{$\begin{array}{l}\mathrm{R}^{2}: 0,294 \\
\text { Prob F tes: } 0,044\end{array}$} \\
\hline \multirow[t]{3}{*}{8} & \multirow[t]{3}{*}{ G. Sitoli } & $\begin{array}{l}\text { C } \\
\text { Log G.Sitoli } \\
\text { bangun }\end{array}$ & $\begin{array}{l}-1,33 \\
3,007\end{array}$ & $\begin{array}{l}0,700 \\
0,521\end{array}$ & $\begin{array}{l}-1,908 \\
5,724\end{array}$ & $\begin{array}{l}0,080 \\
0,0001\end{array}$ & $\begin{array}{l}\text { Sig } \\
\text { Sig }\end{array}$ \\
\hline & & $\begin{array}{l}\text { Log G.Sitoli } \\
\text { dagang }\end{array}$ & 1,234 & 0,433 & 2,849 & 0,0146 & Sig \\
\hline & & \multicolumn{6}{|c|}{$\begin{array}{l}\mathrm{R}^{2} \\
\text { Prob F tes: } 0,751 \\
0,00023\end{array}$} \\
\hline
\end{tabular}

Sumber : hasil olahan

\section{Kota Sibolga}

Produk domestik regional bruto (PDRB) kota Sibolga tahun 2015 atas dasar harga konstan tahun 2010 sebesar Rp 2914510 juta dengan tingkat pertumbuhan secara ratarata sebesar 6,50\% serta PDRB perkapita sebesar Rp 33.69 juta.

Dari tabel di atas menjelaskan bahwa model tingkat kesejahteraan masyarakat kota di Sibolga dapat diterangkan oleh variabel bebas sektor transportasi sebesar $41 \%$, sisa lainya sebesar 59\% dijelaskan oleh variabel bebas lain di luar dari model.

Hasil estimasi fungsi tingkat kesejahtraan di kota Sibolga dipengaruhi oleh sektor transportasi yaitu berpengaruh positif dan signifikan dengan tingkat kepercayaan $99 \%$. Besaran koefisien regresi 9,190 berarti dengan meningkatnya sektor transportasi sebesar Rp 1 akan meningkatkan tingkat kesejahtraan masyarakat Kota Sibolga secara rata-rata sebesar Rp. 9,19. Dalam usaha untuk meningkatkan tingkat kesejahteraan masyarakat kota Sibolga pihak pemerintah dan pelaku ekonomi dapat melakukan efisiensi pada 
kegiatan operasi sektor transportasi baik darat mapun laut karena sektor ini berpengaruh terhadap peningkatan kesejahteraan masyarakat.

\section{Kota Tanjung Balai}

Produk Domestik Regional Bruto (PDRB) Kota Tanjung Balai tahun 2015 atas dasar harga konstan thn 2010 sebesar Rp4637503.9 juta dan tingkat pertubuhan secara rata-rata 5,49\% serta PDRB perkapita sebesar Rp.27.77 juta

Tabel di atas menunjukkan bahwa model tingkat Kesejahteraan masyarakat Kota Tanjung Balai dapat diterangkan oleh variabel bebas sektor bangunan dan sektor jasa sebesar 57\%, sisa lainnya sebesar $43 \%$ diterangkan oleh variabel bebas lain diluar dari model.

Hasil estimasi fungsi tingkat Kesejahteraan masyarakat di kota Tanjung Balai dipengaruhi oleh sektor bangunan yaitu berpengaruh positif dan signifikan dengan tingkat kepercayaan 90\%. Besaran koefisien regresi 3,043. Hal ini menunjukkan meningkatnya sektor bangunan sebesar Rp. 1 akan menyebabkan meningkatkan tingkat Kesejahteraan masyarakat kota Tanjung Balai secara rata-rata sebesar Rp. 3, Variabel lain yang juga mempengaruhinya adalah sektor jasa, berpengaruh positif dan signifikan dengan tingkat kepercayaan 99\%. Besaran koefisien regresi 7,464. Angka ini menjelaskan bahwa meningkatnya sektor jasa sebesar Rp.1 akan menyebabkan meningkatnya tingkat kesejahteraan masyarakat kota Tanjung Balai secara rata-rata sebesar Rp.7.

Tabel diatas menunjukkan nilai uji $\mathrm{F}$ test didapat nilai 0,0003 , ini menunjukkan bahwa variabel bebas sektor bangunan dan sektor jasa secara bersama-sama berpengaruh signifikan terhadap tingkat Kesejahteraan masyarakat kota Tanjung Balai dengan tingkat kepercayaan 99\%. Dalam usaha meningkatkan tingkat kesejahteraan masyarakat kota Tanjung Balai sektor bangunan dan sektor jasa dapat distimulus untuk ditingkatkan lagi volume aktivitasnya.

\section{Kota Pematang Siantar}

Produk Domestik Regional Bruto (PDRB) Kota Pematang Siantar tahun 2015 atas dasar harga konstan tahun 2010 sebesar Rp 7992321.11 juta dan tingkat pertumbuhan secara rata-rata 5,38\% serta PDRB perkapita sebesar Rp 32.31 juta.

Tabel 2 menerangkan bahwa model tingkat kesejahteraan masyarakat kota Pematang Siantar dapat diterangkan oleh variabel bebas sektor bangunan dan sektro jasa sebesar $23 \%$, sisa lainnya sebesar $77 \%$ dijelaskan oleh variabel bebas lainnya diluar dari model.

Hasil estimasi fungsi tingkat kesejahteraan masyarakat Pematang Siantar dipengaruhi oleh sektor bangunan yaitu berpengaruh positif dan signifikan dengan tingkat kepercayaan $90 \%$. Nilai koefisien regresi 1,95 . Nilai ini menerangkan bahwa meningkatnya sektor bangunan sebesar Rp.1 akan menyebabkan meningkatnya tingkat kesejahteraan masyarakat Pematang Siantar secara rata-rata sebesar Rp.1,95. Variabel lainnya yaitu sektor jasa tidak signifikan. Informasi lain bahwa uji $\mathrm{F}$ test nilainya sebesar 0,087. Nilai ini menerangkan bahwa kedua variabel bebas dari model tersebut secara bersama-sama berpengaruh signifikan terhadap tingkat kesejahteraan masyarakat di kota Pematang Siantar.Untuk meningkatkan tingkat kesejahteraan masyarakat kota Pematang Siantar sektor bangunan perlu mendapat perhatian agar volume dari sektor ini dapat menjadi lebih baik lagi. 


\section{Kota Tebing Tinggi}

Produk Domestik Regional Bruto (PDRB) kota Tebing Tinggi tahun 2015 atas dasar harga konstan tahun 2010 sebesar Rp 3234049.9 juta dan tingkat pertumbuhan secara rata-rata 5,31\%, selanjutnya PDRB perkapita sebesar Rp20.63 juta.

Tabel 2 menunjukkan bahwa model tingkat kesejahteraan masyarakat kota Tebing Tinggi dapat diterangkan oleh variabel bebas sektor bangunan dan sektor perdaggangan sebesar 33\%, sisa lainnya sebesar $67 \%$ dijelaskan oleh variabel bebas lainnya diluar dari model.

Hasil estimasi tingkat kesejahteraan masyarakat Tebing Tinggi dipengaruhi oleh sektor bangunan yaitu berpengaruh positif dan signifikan dengan tingkat kepercayaan 95\%. Nilai koefisien sebesar 7,54. Nilai ini menjelaskan bahwa bertambahnya nilai sektor bangunan sebesar Rp.1 akan menyebabkan meningkatnya tingkat kesejahteraan masyarakat Tebing Tinggi secara rata-rata sebesar Rp.7,54. Variabel bebas lainnya yaitu sektor perdagangan berpengaruh positif dan signifikan dengan tingkat kepercayaan 95\%. Besaran koefisien regresi 20,22, angka ini menjelaskan bahwa bertambahnya sektor perdagangan sebesar Rp.1 akan menyebabkan meningkatnya tingkat kesejahteraan masyarakat Tebing Tinggi secara rata-rata sebesar Rp.20,22. Selanjutnya tabel 3 diatas menunjukkan nilai uji $\mathrm{F}$ test sebesar 0,025 , ini berarti bahwa variabel bebas sektor bangunan dan sektor perdagangan secara bersama-sama berpengaruh signiikan terhadap tingkat kesejahteraan masyarakat kota Tebing Tinggi dengan tingkat kepercayaan 95\%.Untuk meningkatkan tingkat kesejahteraan masyarakat kota Tebing Tinggi, sektor bangunan dan sektor perdagangan supaya diusahakan secara optimal.

\section{Kota Medan}

Produk Domestik Regional Bruto (PDRB) kota Medan tahun 2015 atas dasar harga konstan tahun 2010 sebesar Rp 124277481.39 juta dan tingkat pertumbuhan secara rata-rata 6,26\% dan PDRB perkapita sebesar Rp 74.47 juta.

Tabel 3 menerangkan bahwa model tingkat kesejahteraan masyarakat kota Medan dapat diterangkan oleh variabel bebas sektor jasa sebesar 14\% sisa lainnya sebesar $86 \%$ dijelaskan oleh variabel bebas lain diluar dari model.

Hasil estimasi fungsi tingkat kesejahteraan masyarakat Medan dipengaruhi oleh sektor jasa yaitu berpengaruh positif dan signifikan dengan tingkat kepercayan $90 \%$ nilai koefisien regresi sebesar 8,93. Nilai ini memberikan informasi bahwa bertambahnya nilai sektor jasa sebesar Rp.1 berakibat meningkatkan tingkat kesejahteraan masyarakat kota Medan secara rata-rata sebesar Rp.8,93.Dalam upaya meningkatkan tingkat kesejahteraan masyarakat kota Medan sektor jasa perlu dioptimalkan lagi aktivitas operasi.

\section{Kota Binjai}

Produk Domestik Regional Bruto (PDRB) kota Binjai tahun 2015 atas dasar harga konstan tahun 2010 sebesar Rp 6571204.04 juta dan tingkat pertumbuhan secara ratarata $6,00 \%$ selanjutnya nilai PDRB perkapita sebesar Rp 24.83 juta.

Tabel 2 menunjukkan bahwa model tingkat kesejahteraan masyarakat kota Binjai dapat diterangkan oleh variabel bebas sektor jasa dan sektor bangunan sebesar $18 \%$ sisa lainnya sebesar $72 \%$ dijelaskan oleh variabel bebas lainnya diluar dari model.

Hasil estimasi tingkat kesejahteraan masyarakat Kota Binjai dipengaruhi oleh sektor jasa yaitu berpengaruh positif dan signifikan dengan tingkat kepercayan $95 \%$. Nilai koefisien regresi sebesar 14,198. Nilai ini menerangkan bahwa bertambahnya nilai sektor jasa sebesar Rp.1 akan menambah besarnya tingkat kesejahteraan masyarakat Binjai secara rata-rata sebesar Rp.14,19. Variabel bebas lainnya yaitu sektor bangunan 
berpengaruh positif dan signifikan dengan tingkat kepercayaan 95\%. Besar koeisien regresi 6,25 nilai ini menjelaskan bahwa bertambahnya sektor bangunan sebesar Rp.1 akan meningkatkan tingkat kesejahteraan masyarakat Binjai secara rata-rata sebesar Rp.6,25. Selanjutnya tabel 3 menunjukkan nilai uji F test sebesar 0,043, ini berarti bahwa variabel bebas sektor jasa dan sektor bangunan secara bersama-sama berpengaruh signifikan terhadap tingkat kesejahteraan masyrakat kota Binjai dengan tingkat kepercayaan 95\%.Untuk meningkatkan tingkat kesejahteraan masyarakat kota Binjai sektor jasa dan sektor bangunan perlu ditingkatkan lagi aktivitas operasinya.

\section{Kota Padang Sidempuan}

Produk Domestik Regional Bruto (PDRB) kota Padang Sidimpuan tahun 2015 atas dasar harga konstan tahun 2010 sebesar Rp3451082.6 juta dan tingkat pertumbuhan secara rata-rata 4,99\% kemudian nilai PDRB perkapita sebesar Rp16.45 juta.

Tabel 3 menggambarkan bahwa model tingkat kesejahteraan masyarakat kota Padang Sidimpuan dapat diterangkan oleh variabel bebas sektor perdagangan sebesar $29 \%$ sisa lainnya sebesar $71 \%$ dijelaskan oleh variabel bebas lainnya diluar dari model.

Hasil estimasi fungsi tingkat kesejahteraan masyarakat Kota Padang Sidimpuan dipengaruhi oleh sektor perdagangan yaitu berpengaruh positif dan signifikan dengan tingkat kepercayan 95\%. Nilai koefisien regresi sebesar 4,35. Nilai ini menjelaskan bahwa meningkatnya nilai sektor perdagangan sebesar Rp.1 meningkatkan tingkat kesejahteraan masyarakat Padang Sidimpuan secara rata-rata sebesar Rp.4,35. Sehubungan upaya meningkatkan tingkat kesjahteraan masyarakat Padang Sidimpuan sektro perdagangan dianjurkan untuk dioptimalkan lagi aktivitasnya.

\section{Kota Gunung Sitoli}

Produk Domestik Regional Bruto (PDRB) kota Gunung Sitoli tahun 2015 atas dasar harga konstan tahun 2010 sebesar Rp 2703500.08 juta dan tingkat pertumbuhan secara rata-rata 6,16\% dan nilai PDRB perkapita sebesar Rp 19.88 juta.

Tabel 3 menunjukkan bahwa model tingkat kesejahteraan masyarakat kota gunung Sitoli dapat diterangkan oleh variabel bebas sektor bangunan dan sektor perdagangan sebesar $75 \%$ sisa lainnya sebesar $25 \%$ dijelaskan oleh variabel bebas lainnya diluar dari model.

Hasil estimasi tingkat kesejahteraan masyarakat Kota Gunung Sitoli dipengaruhi oleh sektor bangunan yaitu berpengaruh positif dan signifikan dengan tingkat kepercayan 99\%. Nilai koefisien regresi sebesar 3,007. Nilai ini bermakna bahwa bertambahnya nilai sektor bangunan sebesar Rp.1 maka terjadi peningkatan tingkat kesejahteraan masyarakat Gunung Sitoli secara rata-rata sebesar Rp.3. Variabel bebas lainnya yaitu sektor perdagangan berpengaruh positif dan signifikan dengan tingkat kepercayaan 95\%. Besar koeisien regresi 1,23 nilai ini menjelaskan bahwa bertambahnya sektor perdagangan sebesar Rp.1 akan terjadi peningkatan tingkat kesejahteraan masyarakat Gunung Sitoli secara rata-rata sebesar Rp.1,23.

Berikut tabel 3 menunjukkan nilai uji $\mathrm{F}$ test sebesar 0,00023, ini berarti bahwa variabel bebas sektor bangunan dan sektor perdagangan secara bersama-sama berpengaruh signifikan terhadap tingkat kesejahteraan masyrakat kota Gunung Sitoli dengan tingkat kepercayaan $99 \%$.

Untuk meningkatkan tingkat kesejahteraan masyarakat kota gunung Sitoli sektor bangunan dan sektor perdagangan agar ditingkatkan lagi volume operasinya hingga mencapai tingkat yang optimal. 


\section{KESIMPULAN}

berikut :

Berdasarkan hasil analisis yang telah dilakukan dapat ditarik kesimpulan sebagai

1. Sektor ekonomi yang memiliki nilai LQ lebih besar dari satu (berpengaruh terhadap tingkat kesejahteraan masyarakat) kota di Sumatera utara adalah sektor ekonomi bangunan, sektor ekonomi perdagangan, sektor ekonomi transportasi dan sektor ekonomi jasa.

2. Meningkatnya sektor ekonomi yang memiliki nilai LQ lebih besar dari satu seperti yang telah diutarakan diatas dapat meningkatkan tingkat kesehteraan masyarakan kota di Sumatera utara.

\section{DAFTAR PUSTAKA}

Amaluddin, Analisis Spesialisasi dan Pengaruhnya Terhadap Pertumbuhan Ekonomi Antar Wilayah di Provinsi Maluku. Fakultas Ekonomi (Internet). 2012 (Akses 16 Feb 2015). Diambil dari: http://www.amaluddin.blogspot.com

Dylla Novrilasari, Analisis Sektor Unggulan Dalam Meningkatkan Perekonomian dan Pembangunan Wilayah Kabupaten Kuantan Singingi (Internet). 2008 (Akses 16 Feb 2015). Diambil dari: http://www.repository.Ipb.ac.id

Fatmasari Sukesti, Setia Iriyanto, 2011. Pemberdayaan UKM, Menungkatkan Komoditas Unggulan Ekspor UKM Dalam Rangka Pengembangan Ekonomi Daerah, Studi pada UKM Jawa Tengah. Seminar Nasional Ilmu Ekonomi Terapan Fakultas Ekonomi UNIMUS 2011.

Glasson John, Terjemahan Sihotang. 1977, Pengantar Perencanaan Regional. Lembaga Penebitan FE UI, Jakarta.

I Dewa Made Darma Setiawan, Peranan Sektor Unggulan Terhadap Pertumbuhan Ekonomi Daerah Jawa Timur, Bali dan Nusa Tenggara Barat: Pendekatan Input Output Multiregional (Internet). 2007 (Akses 16 Feb 2015). Diambil dari: http://www.portalgaruda.org

Yunie Puspita Sari M, Analisis Pertumbuhan Ekonomi dan Sektor Unggulan di Kabupaten Lamongan. 2004 (Akses 23 Feb 2015). Diambil dari: http://www.researchgate.net

Nasir,M. 2015. Analisis Pengaruh Sektor Unggulan Terhadap Pertumbuhan Ekonomi di Kabupaten Sumatra Utara. Proseding: Seminar Hasil Penelitian Lembaga Penelitian Universitas Negeri Medan Thn.2015 Bidang Sain,Teknologi,Sosial,Bahasa dan Humaniora.Lembaga Penelitian Universitas Negeri Medan

Samuelson, A Paul dan William DN. 2004, Analisis Pertumbuhan Perencanaan Regional PT. Media Global Edukasi, Jakarta.

Sjafrizal. 2012, Ekonomi Wilayah dan Perkotaan Padang. Rajawali Pers, Jakarta.

Tarigan Robinson. 2012, Ekonomi Regional Teori dan Aplikasi. Penerbit Bumi Aksara, Jakarta.

Todaro Michael P. 2000, Ekonomi Pembangunan, Terjemahan oleh Haris Munandar. edisi ke lima. Bumi Aksara, Jakata. 